\title{
THE IMPACT OF THE REVISED GOVERNMENT POLICY ON THE SUSTAINABILITY OF LOBSTERS IN INDONESIA
}

\author{
SHAFITRI ARINDYA RAMADHANTY \\ Faculty of Business and Economics, Universitas Surabaya \\ arindyar13@gmail.com \\ DOI 10.31219/osf.io/vad29
}

Indonesia is an archipelagic country consisting of clusters of islands, sums up to more than 17,000 large and small islands by December 2019. As an archipelagic country, two thirds of the country is water, hence the remarkable marine resources. While a variety of marine resources are beneficial for the country and its people, it inevitably becomes the target of fishermen from various countries. These fishermen are often equipped with modern fishing equipments that are able to obtain large-scale catches, and therefore making the domestic fishermen with conventional methods and stringent regulation on fishing equipments suffer from the competition. In respond to the problem, the Indonesian government, through the Ministry of Marine Affairs and Fisheries has attempted to revise regulations on the capture fisheries sector and prepared specifications on fishing equipment over the years. Specifically, the government attempted to revise the 18 regulations on the capture fisheries sector that hinder the business community and replaced fishing equipments that are considered detrimental to the environment by developing 89 environmentally friendly specifications.

However, the decision raised an issue as one of the revised government policies have caused a polemic among the stakeholders. This polemic over the Minister of Marine Affairs and Fisheries Regulation Number 12 of 2020 regarding lobsters and crabs management in the territory of Republic of Indonesia. Another issue that occur and caused unrest is the revised regulation that allows the legalization of the previously prohibited fishing equipments, which include cantrang, payang, shrimp trawl, and similar fishing equipments that fall into the category of trawl. Although the 
government argues that they have compiled a four year roadmap for lobster cultivation starting on 2020 and the production value of cultivated lobsters is projected to increase to 1.73 billion rupiah in 2024 , there are still doubts on the revised government policy and the legalization of prohibited fishing equipments.

One of the doubts was raised due to the inconsistency of the revised policy with the economic constitution mandate regulated in Article 33 of the 1945 Constitution of the Republic of Indonesia paragraph 3 and 4 with the argument that lobster seeds are extractive natural resource that are generally produced by hatcheries and are basically taken from nature. And thus, the management of lobster export should fall into the responsibility of the state and the government needs to be transparent to avoid confusions, although the government was still adamant to proceed with the implementation of the regulation. Subsequently, the legalization of the prohibited fishing equipments was feared to trigger horizontal conflicts among the fishermen communities and that the government was accused of favoring one party over the other.

Like many other commodities, the price movements of lobsters and lobster seeds are primarily determined by demand and supply in the market, both in domestic and international market. A sharp increase in the international demand will encourage the issuance of new regulations concerning the cultivators or fishermen welfare, although the new regulations often disregard the sustainability of lobsters in Indonesia. Thus, The Roma Group invites stakeholders to be more aware and are willing to have a broader perspective as to think ahead of time and space. As an important source of income and a crucial component of production activities in both industry and services, natural resources - in this case is marine resources - belong to the public are likely to be overexploited by taking and using shortcuts such as nonenvironmentally friendly fishing equipment like cantrang or modern fishing equipment to get large-scale catches.

The report of Roma Group released in "The Limits to Growth" - a report commissioned by Roma Group on the exponential economic and population growth with finite resources supply - in 1972 (Meadows, Meadows, Randers, \& Behrens III, 1972) conveys that the world is likely to fail due to the limited number of important natural resources while the world consumption level continues to soar. Furthermore, renewable natural resources suffered lots of 
damage and the environmental capacity is gradually become limited. Therefore, in the context of lobster production, the authors of "The Impact of Minister of Marine Affairs and Fisheries Regulation Number 12 of 2020 on the Sustainability of Lobster in Indonesia" adopt the Optimal Pigovian Tax (Suparmoko \& Maria, 2000) to balance the benefits and the environmental damage of lobster production.

The research uses a qualitative descriptive method with a lobster case study associated with the problems concerning public policies implementation in the community, especially cultivators and fishermen. Moreover, the research is supported by both primary and secondary data. The primary data comes from the informants - in this case is lobster cultivators in Paremas Village and Telong Elong Village, Jerowaru Sub-District, East Lombok Regency, West Nusa Tenggara as well as the representative of the Indonesian Marine Fish Cultivators Association - while the secondary data comes from the Ministry of Marine Affairs and Fisheries of the Republic of Indonesia. Consequently, the data gathered from both primary and secondary sources were able to point out the loopholes of the revised regulation and the lobster cultivation roadmap. Thus, the authors come up with the economic management strategy for lobster accordingly to the SWOT analysis of the lobster cultivation roadmap and revised regulation. Moreover, these strategies were developed with the aim to achieve maximum social welfare, especially for lobster cultivators and fishermen in Indonesia.

Finally, the enactment of the revised regulation, the Minister of Marine Affairs and Fisheries Regulation Number 12 of 2020, are proven to have more of a negative than positive impact on the sustainability of lobsters in Indonesia and favor one party over the other. Therefore, the regulation should not be implemented immediately without thorough considerations of the parties involved (Tayibnapis, Wuryaningsih, \& Gora, 2020).

\section{References}

Meadows, D. H., Meadows, D. L., Randers, J., \& Behrens III, W. W. (1972). The Limits to Growth. Potomac Associates - Universe Books.

Suparmoko, M., \& Maria, R. S. (2000). Ekonomi Lingkungan (1st ed.). Yogyakarta: BPFE.

Tayibnapis, Z. A., Wuryaningsih, L. E., \& Gora, R. (2020, October). The Impact of Minister of Marine Affairs and 
Fisheries Regulation Number 12 of 2020 on the Sustainability of Lobster in Indonesia. International Journal of Multicultural and Multireligious Understanding, 7(9), 130-136. doi:http://dx.doi.org/10.18415/ijmmu.v7i9.1931 